\title{
CZY SMUTNY I CKLIWY POTRAFI SIĘ CIESZYĆ? RZECZ O GRZEGORZU Z NAZJANZU
}

Sylwetkę Grzegorza z Nazjanzu trudno jest określić w sposób jednoznaczny. Badacze zajmujący się historią jego życia i twórczością, bardzo często dochodzą do rozbieżnych wniosków. Świadectwem jednostronnej interpretacji może być chociażby utarte powiedzenie, ,że Grzegorz był potulny i łagodny, że nie podnosił głosu, a gdy coś nie odpowiadało jego przekonaniom lub nastrojom, umiał tylko zamykać się w sobie, uciekać na pustynię i rozczulać się nad sobą"1.

Autorzy podkreślający te cechy charakteru, nadzwyczaj mocno, czynią więc z Grzegorza postać rzewną jedynie i pozbawioną osobowości. Kreuja przez tak formułowane sądy wypaczony obraz człowieka - jednostronny i z punktu widzenia rzetelności badań - nieuczciwy.

Kim był więc Grzegorz z Nazjanzu? Jak winien być ukazany, by prawda o nim i o jego charakterze ułatwiała również odbiór jego dzieł - niełatwych w lekturze, zakrytych przecież dodatkowo bogactwem retorycznych ornamentów i figur?

Niniejsze opracowanie nie stanowi opisu psychologicznego osobowości Grzegorza. Ma ono za zadanie przedstawić jego postać w świetle realiów życia i duchowych doświadczeń. W tak bowiem pojętym kontekście „smutek i ckliwość" człowieka, bardzo dojrzałego duchowo, rozdartego jednak w życiowych wyborach, odnaleźć mogą swe uzasadnienie, a także podlegać innej ocenie, głębszej i wykluczającej nieuprawnione sądy. Znając przyczyny trudności i zmartwień, łatwiej również odnaleźć źródła życiowej radości. Smutek bowiem może być wyrazem zatroskania o te sprawy, których uczciwe przeprowadzenie i realizacja przynosi życiowe spełnienie i szczęście.

1. Ból życia w świecie i tęsknota za pustynią. W sercu Grzegorza z Nazjanzu bardzo głęboko zakorzenione było pragnienie oddania się na wyłączną służbę Bogu. Już podczas pobytu studenckiego w Atenach, wraz z Bazylim, przyobiecali sobie, że oddadzą się w pełni życiu „filozoficznemu” (to jest

"Ks. dr hab. Dariusz Zagórski, prof. UMK - kierownik Zakładu Historii Kościoła Starożytnej i Średniowiecznej na Wydziale Teologicznym Uniwersytetu Mikołaja Kopernika w Toruniu; e-mail: ecce@op.pl.

${ }^{1}$ J.M. Szymusiak, Grzegorz Teolog. U źródet chrześcijańskiej myśli IV wieku, Poznań 1965, 97. 
ascetycznemu) i dążeniu ku duchowej doskonałości²:

„Gdy zaś po pewnym czasie wyznaliśmy sobie nasze wspólne pragnienie, by szukać właściwej filozofii, odtąd staliśmy się dla siebie wszystkim - żyjąc pod jednym dachem, dzieląc jeden stół, jako nierozłączni przyjaciele; mieliśmy oczy zwrócone na jeden cel i ciągle rozwijaliśmy w sobie nawzajem [nasze] pragnienie, tak, by stawało się coraz gorętsze i mocniejsze. Pragnienia cielesne, jako dotyczące rzeczy przemijających, przemijają i więdną jak wiosenne kwiaty [...]. Pragnienia zaś miłe Bogu i czyste są trwalsze, ponieważ dotyczą spraw niezmiennych; i im piękniejszy obierają sobie przedmiot uwielbienia, tym bardziej wiążą swoich wyznawców i z sobą, i ich samych wzajemnie. Bo takie jest nad nami prawo miłości duchowej”’3.

Ten zapał do duchowego postępu, plan na życie doskonalsze i poświęcone Bogu, zaczyna się jednak od samego początku komplikować. Zarówno Grzegorz, jak i Bazyli, ,by zaspokoić chorobliwą żądzę ziomków, którzy jak gdyby zwrotu długu domagali się" tego, dali wyraz swym umiejętnościom retorycznym. Grzegorz udzielał lekcji wymowy, czego świadectwem jest List $3^{4}$.

Cierpień o charakterze duchowym przymnożyć mógł Grzegorzowi fakt, że Bazylemu udaje się ostatecznie zrealizować młodzieńcze marzenia ${ }^{5}$. Nie posądzając Nazjanzeńczyka o zazdrość, trudno nie uznać jego życiowej przegranej, rezygnacji z tak ważnych planów, co wprowadzić musiało w jego życie smutek i przygnębienie, przygaszane tylko chwilami radością płynącą z uczynionej przez siebie namiastki pustelni, w ramach której oddawał się rozmyślaniom nad Pismem Świętym i surowemu umartwieniu ${ }^{6}$.

Za znaczący ciężar, przytłaczający człowieka pragnącego poświęcić swe życie kontemplacji, uznać należy troskę Grzegorza o majątek rodziców. Ten, który uważał siebie za umarłego dla świata, „włóczyć [się] musiał po sądach lub bronić przed wygórowanymi wymaganiami cesarskich urzędników podatkowych"7.

2. Bolesne doznania niesione przez życie. Przyczyną smutków Kapadocczyka, jego wewnętrznego zadumania, były z całą pewnością nieobce ludzkiemu doświadczeniu bolesne doznania niesione przez życie. W ramach

\footnotetext{
${ }^{2}$ Por. tamże, s. 73; zob. J. Bernardi, Saint Grégoire de Nazianze: Le théologien et son temps

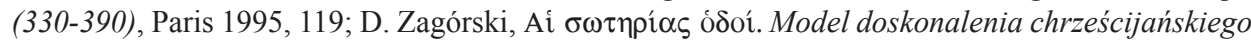
w świetle ekshortacji pastoralnych Grzegorza z Nazjanzu, Toruń 2007, 23.

${ }^{3}$ Gregorius Nazianzenus, Oratio 43, 19, w. 1-14, ed. J. Bernardi, SCh 384, Paris 1992, 162, thum. zbiorowe: Św. Grzegorz z Nazjanzu, Mowy wybrane, Warszawa 1967, 487-488.

${ }^{4}$ Por. tenże, Epistulae 3, ed. P. Gallay: Saint Grégoire de Nazianze, Lettres, I, Paris 1964, 2-3, tłum. J. Stahr: Św. Grzegorz z Nazjanzu, Listy, POK 15, Poznań 1933, 4.

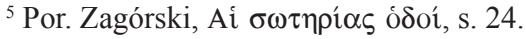

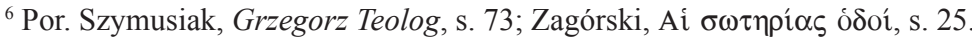

${ }^{7}$ Szymusiak, Grzegorz Teolog, s. 73.
} 
niniejszego opracowania przedstawione zostaną tylko wybrane wydarzenia, wyraźnie odciskające swe piętno na osobowości naszego autora.

Grzegorz przeżył bardzo boleśnie śmierć bliskich mu osób. W niewielkiej odległości czasowej zmarli: jego brat Cezary i siostra Gorgonia. Nasz autor o brata troszczył się znacząco, by ten nie przetracił życia na sprawach doczesnych. Tak pojęta dbałość o bliską i umiłowaną osobę, w człowieku traktującym doskonalenie i ludzkie zbawienie za rzecz najistotniejszą, rodziła w konkretnych sytuacjach życiowych smutek i udręczenie:

„Żal mi było, iż tak wielki talent marnował się w sprawach przyziemnych, a dusza tak zdolna do spraw Bożych ciaggle zajmowała się sprawami publicznymi, podobna do słońca ukrytego za chmurami"».

Przerażający ślad głębokiego zranienia, uzewnętrzniony w Mowie 7 oraz w szesnastu krótkich epitafiach poświęconych osobie Cezarego, thumaczy wielką żałość Grzegorza po jego śmierci. Nazjanzeńczyk w Liście 30 odkrywa nam rąbek swego wnętrza i bolejącego serca, opisując odejście pierwszej bliskiej mu osoby9:

„Cezarjusza już nie mam! Wołam tak, choć niefilozoficzne to uczucie. Drogie mi wszystko po Cezarjuszu; gdy zobaczę kiedy pamiątkę po nim, obejmuję ją i do serca przyciskam; zdaje mi się, że go widzę, mam przy sobie i rozmawiam z nim"10.

Równie bolesnym przeżyciem była dla Grzegorza śmierć jego starszej siostry - Gorgonii. Uczcił ją „Grzegorz mową pogrzebową, w której stawia zmarłą za wzór wszystkim kobietom żyjącym w małżeństwie" ${ }^{11}$. Cierpienie związane z jej „odejściem”"12 dotknęło nie tylko naszego autora, ale także wszystkich domowników i znajomych:

„Ale o mało nie przeoczyłem pięknego szczegółu tej śmierci! Lecz może nie pozwoliłbyś na to, ojcze jej duchowny, któryś pilnie obserwował to piękne zjawisko i nam je opowiedział; a cenne jest dla jej pochwały, cenne także dla podkreślenia jej cnoty i uwydatnienia jej chęci odejścia. Ale dreszcz jakiś mnie przelatuje i zbiera mi się na łzy, kiedy wspominam ten cudowny fakt. Już umierała i wydawała ostatnie tchnienie, otoczona jak gdyby chórem domownikami i znajomymi [...]. Miłość wszystkich brała udział w tej agonii - jedni chcieliby coś usłyszeć, by żywsze wspomnienie zachować o niej,

${ }^{8}$ Gregorius Nazianzenus, Oratio 7, 15, ed. M.A. Calvet-Sebasti, SCh 405, Paris 1997, 216, w. 21-23, thum. J.M. Szymusiak, Grzegorz Teolog, s. 298.

${ }^{9}$ Por. Szymusiak, Grzegorz Teolog, s. 132.

${ }^{10}$ Gregorius Nazianzenus, Epistula 30, ed. Gallay, I, s. 37, POK 15, 44.

${ }^{11}$ Szymusiak, Grzegorz Teolog, s. 134.

${ }^{12}$ Por. Gregorius Nazianzenus, Oratio 8, 19, w. 8-10, SCh 405, 288, Grzegorz Teolog, s. 312: „Pragnęła tego odejścia (Flp 1, 23) - bardzo bowiem ufała Temu, który ją wołał - a przebywanie z Chrystusem więcej ceniła niż cokolwiek na ziemi”. 
drudzy zaś chcieliby coś powiedzieć, ale nikt nie miał odwagi. Tłumiono łzy, gdyż nie ma lekarstwa na bóle smutku"13.

Nie upłynęło wiele czasu, a po Gorgonii umiera cioteczny brat, Eufemiusz $^{14}$. Jak słusznie zauważa Norbert Widok: „Dla Grzegorza rodzinna żałoba była okresem głęboko egzystencjalnych przemyśleń na temat losu ludzkiego i tajemnicy człowieka w perspektywie zbawczej"15. Jan Maria Szymusiak dodaje, że „od tego okresu, tak obfitującego w żałobę i ból, Grzegorz zamknie się w sobie. Nie można się dziwić, że odtąd jego dzieła stają się bezustannym wołaniem do Boga o zmiłowanie, często zabarwionym pewną goryczą"16, czego przykładem jest choćby niniejszy fragment poezji:

„Zawiedziony zostałem, Chryste, zbyt ufając

Tobie! Wzniesiony w górę, ciężko znów upadłem, ale Ty mię znów podnieś, albowiem spostrzegłem, żem swą własną igraszką. Gdybym jeszcze został wywyższony, to znowu upadłbym rozbity.

Jeśli mię przyjmiesz, dobrze; jeśli nie, zginąłem.

Czy tylko dla mnie dobroć Twa jest wyczerpana?"'17

$\mathrm{Na}$ wiosnę 374 r., w wieku około stu lat, umiera ojciec Grzegorza z Nazjanzu, Grzegorz Starszy. W początku 375 r. odchodzi do Pana również jego matka. Grzegorz „doznając uczucia pustki” ${ }^{18}$ po śmierci rodziców udaje się do Izaurii, by tam poświęcić się kontemplacji i przebywaniu w samotności.

Kolejnym doświadczeniem cierpienia i smutku stała się śmierć Bazylego. który zmarł 1 stycznia 379 r. w Cezarei. Grzegorz „utracił swego duchowego brata. Pozostał całkowicie sam. Nie był na pogrzebie przyjaciela. Mowę pogrzebową wygłosił brat zmarłego, Grzegorz z Nyssy"19.

W korespondencji skierowanej do tego ostatniego, po otrzymaniu wiadomości o odejściu Bazylego, nasz Autor zawarł następujące słowa:

„I to jeszcze spotkało mój utrapiony żywot, żem usłyszał o śmierci Bazylego, o odlocie tej świętej duszy! Odleciał on od nas, by przebywać u Pana (por.

${ }^{13}$ Tamże 8, 22, w. 1-15, SCh 405, 292-294, Grzegorz Teolog, s. 313.

${ }^{14}$ Por. tenże, Epitaphion 32, PG 38, 26, thum. Z. Kubiak, w: Szymusiak, Grzegorz Teolog, s. 578: „Zabłysnął wśród ludu Eufemios - jakże wspaniałym blaskiem! Lecz na krótko. Błyskawicy łuna - nie trwa długo.

Wiedzą wielką zabłysnął i urodą swą, i mądrością. Był niegdyś chlubą Kapadocji. Dziś jest - jej smutkiem".

${ }^{15}$ N. Widok, Grzegorz z Nazjanzu, Kraków 2006, 43-44. Por. Szymusiak, Grzegorz Teolog, s. 135.

${ }^{16}$ Szymusiak, Grzegorz Teolog, s. 135.

${ }^{17}$ Tenże, Carmina II 1, 67, PG 37, 1408, tłum. T. Sinko - J. Birkenmajer - I. Hołowiński, w: Szymusiak, Grzegorz Teolog, s. 548.

${ }^{18}$ Widok, Grzegorz z Nazjanzu, s. 59.

${ }^{19}$ Tamże, s. 59-60. 
2Kor 5, 8), do czego przez całe życie się zaprawiał. A ja obok innych rzeczy i tego zostałem pozbawiony wskutek ciagle jeszcze ciężkiej i bardzo niebezpiecznej choroby, bym mógł ucałować jego święte popioły i być przy tobie, dzielnie filozofującym, i wspólnych naszych przyjaciół pocieszać. Bo ta opustoszałość Kościoła, pozbawionego takiej chluby, obdartego z takiego wieńca: na to patrzeć niepodobna, a słyszeć - ból, jeśli się ma rozum! Masz wielu przyjaciół i słów pocieszenia, a jednak w nikim takiej pociechy nie znajdziesz, jak w sobie samym i we wspomnieniach o nim"20.

Jak wielkiego bólu rozstania doświadczał Grzegorz w związku ze śmiercią Bazylego widać w Liście 80. Wspomina w nim również swego brata Cezarego i zmarłych rodziców:

„Pytasz, jak mi się wiedzie. Bardzo smutno. Bazylego nie mam, Cezarjusza nie mam: duchowego brata i cielesnego. «Ojciec mój i matka moja opuścili mnie» (Ps 27, 10)"'21.

Przywołane wydarzenia dotykające Grzegorza z Nazjanzu, związane z odchodzeniem wszystkich bliskich jego sercu osób, jednoznacznie ukazują jak doświadczony może być człowiek i jak to doświadczenie łączy się z rewizją poglądu na świat. Cierpienia wpływają również na zmiany w wewnętrznym uformowaniu człowieka, którego oblicze częściej zakryte zostaje smutkiem i surowością.

Inny rodzaj trosk, które wystawiały życiowe siły Grzegorza na próbę, wiązał się z dbałością naszego autora „o pokój ${ }^{22}$ w Kościele i o świętość pracujących w nim pasterzy"23. J.M. Szymusiak za wielką siłę Grzegorza uznaje to, „że w każdej okoliczności występował jako mąż Boży, nigdy we własnym interesie, zawsze troszczący się o wartości wieczne, ale także liczący się z codzienną rzeczywistością"24.

Kapadocczyk przedstawiał więc ,manewry” niegodnych przywódców $(\pi \rho \circ \sigma \tau \alpha \dot{\alpha} \alpha \iota)^{25}$ i obnażał ich naznaczone grzechem życie. Wspominał o błędach w decyzjach, o prywacie „,kolegów w episkopacie”, których nie zawahał się nazywać ,katami”, przelewającymi duchową krew wiernych ${ }^{26}$.

\footnotetext{
${ }^{20}$ Gregorius Nazianzenus, Epistulae 76, ed. Gallay, I, s. 93-94, POK 15, 104.

${ }^{21}$ Tamże 80, ed. Gallay, I, s. 103, POK 15, 113.

${ }^{22}$ Por. D. Zagórski, Umiar w gorliwości-gwarantem pokoju (pasterskie wskazania Grzegorza z Nazjanzu), AnCra 38-39 (2006-2007) 411-420.

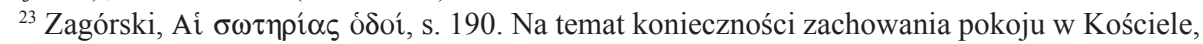
a także fatalnych konsekwencji jego braku we wspólnocie zob. M. Serra, La carità pastorale in San Gregorio Nazianzeno, OCP 21 (1965) 342.

${ }^{24}$ Szymusiak, Grzegorz Teolog, s. 251.

${ }^{25}$ Termin używany przez Grzegorza na oznaczenie biskupów. Odzwierciedla on nową i znaczącą rolę społeczną, do której pełnienia zostają wezwani biskupi w kontekście historycznym IV wieku.

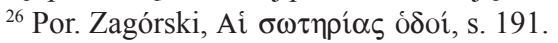


Na sercu leżała Grzegorzowi troska o Kościół w wymiarze powszechnym, co przejawiało się w wezwaniach do obsadzania wakujących katedr biskupich. Nasz autor apelował o wybór właściwych kandydatów na nie, a także bronił tych pasterzy Kościoła, na których padały niesłuszne i fałszywe posądzenia ${ }^{27}$. Prośby o wsparcie w tego typu kwestiach Kapadocczyk kierował również do osób, które byłyby w stanie udzielić mu wsparcia we wspomnianych zabiegach ${ }^{28}$.

Jeszcze jedną kwestią, bardzo ważną dla Grzegorza, która spędzała mu sen z powiek, była troska o czystość doktryny. Zwalczał on zacięcie wszelkie wypaczenia i herezje, a także bronił dogmatów. Nasz autor całkowicie zapominał w tym kontekście o sobie, o swoim stanie zdrowia, o ocenach innych. Tak jak unikał zgrzytów w kwestiach osobistych, tak nie ustępował nigdy, kiedy miał bronić prawdy, co widać chociażby w przypadku walki o czystość nauczania odnośnie do Trójcy Świętej29:

„I to jest dziełem Ducha Świętego, i to jest owocem mojej orki. Nie mam zwyczaju podawać nauki w sposób niekulturalny; nie rzucam się na przeciwnika z obelgami, jak to sobie pozwala większość polemistów, którzy zamiast naukę zwalczać, zwalczają ludzi, a często zdarza się, że ukrywają słabość swoich argumentów pod zasłoną takich obelg. Postępują jak mątwa, o której się mówi, że wydziela czarną ciecz przed siebie, by się ukryć przed napastnikiem lub by sama polować mogła dzięki tej zasłonie. Ja mam zwyczaj otwarcie zapowiadać, że walczę w sprawie Chrystusa i walkę przeprowadzę w duchu Chrystusa, który miłuje pokój, jest łagodny (por. Mt 11,29) i który na siebie wziął naszą słabość (por. Iz 53, 4). Ale nie powołuję do pokoju z uszczerbkiem dla prawowiernej nauki, nie idę na ustępstwa, by sobie uzyskać opinię łagodności. Nie można przecież osiagnąć dobra w sposób nieuczciwy"30.

Powyższy opis jednoznacznie wskazuje na swoiste „środowisko” życiowe Nazjanzeńczyka. Ono to - poznane - pozwala na bardziej obiektywną ocenę osoby Grzegorza, jego zachowań i podejmowanych decyzji. Analiza wydarzeń, tragedii życiowych, a także trosk naszego autora, przy rzetelnym spojrzeniu na nie, upoważnia do jednoznacznego stwierdzenia, że nie stanowiły one dla Kapadocczyka jedynie źródła przesyconego pesymizmem zgorzknienia, ale wyzwalały w nim nadzieję i optymizm. Potwierdzeniem tego niech staną się te fakty z życia i fragmenty twórczości naszego autora, które na zasadzie antytezy uzupełnią wcześniej przywołane wypowiedzi. Ich pozytywny wydźwięk zdaje się obalać zbyt uproszczone oceny, płynące ze strony nieuważnych badaczy.

\footnotetext{
${ }^{27}$ Por. tamże, s. 192.

${ }^{28}$ Por. tamże.

${ }^{29}$ Por. Szymusiak, Grzegorz Teolog, s. 251.

${ }^{30}$ Gregorius Nazianzenus, Oratio 42, 13, w. 3-14, SCh 384, 76-78, Grzegorz Teolog, s. 385.
} 
3. Źródła radości i sila pocieszenia. Wspomniana relacja Grzegorza z Bazylim, ich wspólne młodzieńcze marzenia i plany, nie jawiły się dla naszego autora jedynie jako źródło niespełnionych tęsknot, ciagłych frustracji, czy życiowego obciążenia. Tak mogłoby wynikać z wcześniej przywołanych tekstów, pełnych nostalgii związanej z pozostawieniem pustyni, czy z brakiem przyjacielskich spotkań. Niektórzy z krytyków dopatrzyliby się nawet dodatkowych obciążeń tego swoistego partnerstwa, w rzekomej ,głębszej niezgodzie” i „braku zgrania charakterów”, mających wypływać ze wzajemnej korespondencji obu.

Uznać jednak trzeba za właściwą rzecz całkowicie przeciwną - wspomnieć mianowicie o wielkim dowcipie i humorze płynącym $z$ tych przesyconych retoryką listów. J.M. Szymusiak mówi o tym, by „poznać konkretną sytuację [życia Grzegorza i Bazylego] i podchodzić do nich jak do normalnych ludzi, którym szkolne nawyki, przyswojone w ciagu piętnastu lat studiów, jeszcze nie wyszumiały z głowy. Gdy tylko chwytają za pióro, cisną im się na papirus stare wzory i sposoby wyrażania" ${ }^{31}$, rozbawiające przyjació 1 - przecież literackich smakoszy.

Również przywołane wcześniej doświadczenia związane z umieraniem bliskich osób nie objawiały Grzegorza jako człowieka bolejącego tylko i zatrzymującego się na etapie żałoby. W Mowie 7 (Na cześć brata swojego Cezarego) podaje on rzadko spotykany opis szczęśliwości nieba, pełen reminiscencji platońskiej nauki, w którym losy ciała jednak opisane są w pełni w duchu chrześcijańskim ${ }^{32}$. Wszystkie tego typu pocieszenia wydają się nie tylko wymogiem strukturalnym konstruowanych mów. Przebija z nich optymizm i pociecha, głębsze zrozumienie rzeczywistości i nadzieja.

W takim świetle ukazana zostaje również zmarła siostra Grzegorza - Gorgonia. Mówca w Pochwale Gorgonii mówi o niej jako o obywatelce „górnej Jerozolimy”33, której ,stan obecny” jest zbyt piękny i wzniosły, by można go porównać ze światem widzialnym ${ }^{34}$.

W sytuacjach wspomnianych trudności, związanych z czystością doktryny, Grzegorz z Nazjanzu nie może być postrzegany jako smutny wyłącznie, bo zatroskany o rzeczy istotne i ważne. Widać w nim wiele radości i wewnętrznego zapału, gdy wspomina o „swojej Trójcy Świętej” czy przedstawia prawdy czysto brzmiącej chrystologii.

Widać w końcu Grzegorzowe ciepło wewnętrzne i pogodę ducha w listach, zwłaszcza tych, które niosą wsparcie i przynaglają do radowania się. Świadczyć może o tym choćby korespondencja z Filagriuszem, prawdopodobnie retorem i adwokatem z zawodu, doświadczającym cierpienia, płynącego z cho-

\footnotetext{
${ }^{31}$ Szymusiak, Grzegorz Teolog, s. 78.

32 Por. tamże, s. 131.

${ }_{33}$ Gregorius Nazianzenus, Oratio 8, 6, w. 8, SCh 405, 256, Grzegorz Teolog, s. 306.

${ }^{34}$ Por. tamże 8, 23, w. 1-2, SCh 405, 296, Grzegorz Teolog, s. 314.
} 
roby. Grzegorz jako główny cel stawia sobie pocieszenie w słabości. Leokadia Małunowiczówna stwierdza, że nie da się w sposób jednoznaczny opisać,

„z powodu jakich cierpień fizycznych trzeba było go pocieszać; musiały to być niedomagania poważne i długie, jak wynika z treści listów oraz z ilości pism konsolacyjnych, ale nie utrata wzroku, do której nawiązuje Ep. 34. Na podstawie zachowanej korespondencji można stwierdzić zmianę $\mathrm{w}$ sposobie znoszenia choroby przez Filagriusza: z początku było to przygnębienie i smutek, potem cierpliwość, a nawet radość. Nie da się dziś ustalić, czy przemiana dokonała się właśnie na skutek pouczeń i wskazówek otrzymanych od przyjaciela" ${ }^{35}$.

Podobnie jak na Filagriusza Grzegorz wpływał również na innych. Wymienić należy tu brata jego - Cezarego, Grzegorza z Nyssy, Eudoksjusza, czy Nemezjusza. Nasz autor zwracał uwagę na wartości absolutne ${ }^{36}$. Nie był on, jak podkreśla to Jan Stahr, „,wrogiem radości życia - chciałby je tylko widzieć czystym i uświęconym. Dowodzą tego choćby [...] piękne liściki weselne, w których taki żywy wyraża się udział w radości krewnych czy znajomych"37.

$* * *$

W świetle przedstawionych faktów z życia Grzegorza z Nazjanzu, istotnych wydarzeń wpływających na jego formację duchową, intelektualną, jeszcze raz spytać należy, czy zewnętrzny smutek i ckliwość człowieka musi być koniecznie wyrazem braku radości życia i optymizmu.

${ }^{35}$ L. Małunowiczówna, Listy konsolacyjne i mowy żałobne Grzegorza z Nazjanzu, RTK 25 (1978) z. 4, 178. Autorka (Listy konsolacyjne, s. 183) omawia również List 33. (ed. Gallay, I, s. 42-43, POK 15, 50-51), skierowany do Filagriusza, posiadający charakter konsolacji „w różnych innych zmartwieniach”: „W Ep. 33 Grzegorz występuje jako kierownik duchowy, by uspokoić przyjaciela, utwierdzić go w przekonaniu, że słusznie postępuje wbrew zarzutom i krytyce ze strony innych. Oto «pospolitacy» zarzucali Filagriuszowi, że przy swoim złym stanie zdrowia dba nadmiernie o upiększenie posiadłości, wkładając w to zbyt wiele wysiłku. Ponieważ przyjaciel zachowuje tu umiar, nie kieruje się chciwością, a szuka ulgi w cierpieniu fizycznym, konsolator nie widzi powodu do przygany, ufając jego rozumowi i trosce o sprawy duszy. Zresztą własne sumienie i Bóg mają być doradcami w cierpieniu i sprawach z nim związanych".

${ }^{36}$ Por. J. Stahr, Wstęp, w: Św. Grzegorz z Nazjanzu, Listy, POK 15, Poznań 1933, XXIX-XXX.

${ }^{37}$ Tamże, s. XLVII-XLVIII. Por. Gregorius Nazianzenus, Epistulae 231, ed. P. Gallay: Saint Grégoire de Nazianze, Lettres, II, Paris 1967, 122-123, POK 15, 277-278: „Euopjon najmilejsza! - Zatem wesele blisko - życie ma podstawę - ojców modły spełnione! A mnie tam nie ma, choć ja osobliwie winienem być i modlić się z wami. Wszakżem ci to obiecał, bo nadzieja czaiła się pod tęsknotą - pragnienie bowiem skłonne jest do złud. Kilka razy wybierałem się, kilka razy zawahałem się - w końcu uległem chorobie. [...] Ja wam zaśpiewam moją pieśń weselną! «Niech błogosławi wam Pan z Syjonu» (Ps 128, 5), niech sam ten związek zespoli, «i oglądaj syny synów twoich» (Ps $128,6)$, żeby wiele nie mówić, nawet od ciebie lepszych! Obecny o to bym się dla was modlił i teraz się modlę". 
Odpowiedź w wypadku naszego autora zdaje się być oczywista. Smutek i ckliwość nie objawiają natury Grzegorza, ale raczej jego sposób podejścia do rzeczywistości i otoczenia. Wrażliwość serca, w której sam dostrzegał ,jedną z bolączek swojego życia”, nazywając ją nawet „rdzą duszy ludzkiej”, wystawiała go na cierpienia i trudy, których znoszenie było niełatwe i zamykało go na świat, łącząc jeszcze ściślej z Chrystusem - Bogiem i wiernym przyjacielem $^{38}$.

Radość stanowiła więc wyraz życiowej dojrzałości. Jej przedmiotem były raczej rzeczy duchowe, dalekie od zwykłej wesołkowatości i pustego śmiechu. Nie odczłowieczało to jednak naszego autora i nie czyniło zeń niedostępnego ponuraka. Właściwie pojętym szczęściem mógł bowiem podnosić ze smutku cierpiącego i załamanego, a innym wskazywać właściwy sposób radowania się i korzystania z życia.

\section{IS A SORROWFUL AND SENTIMENTAL ONE ABLE TO ENJOY? THE THING ABOUT GREGORY OF NAZIANZUS}

\section{(Summary)}

This article is aimed as an objective description of the character of Gregory of Nazianzus, written in the light of the realities of life and spiritual experience, which may revise the existing opinions about the Author, relating to his personality, attitude and choices, as they are often one-sided, unjust and wrongful. This study presents Gregory as pastor concerned for the Church who grieves for its internal tearing as well as for ,his colleagues in episcopacy” self-interest. It treats about personal aspects of his life often marked by suffering and difficult experience. In this context, the article also points to the source of joy and optimism of life, which is support for the needy and those who lost the meaning of life.

\footnotetext{
${ }^{38}$ Por. Szymusiak, Grzegorz Teolog, s. 252.
} 
